By HANS MULLER

\title{
The Management of College Library Book Budgets
}

Hans Muller, research assistant at the Graduate Library School of the University of Chicago, prepared this paper for a meeting of the College Libraries Section at the Boston Conference.

T IBRARY PRACTICES are often tough and L stubborn. Once established, they tend to become inhospitable to change. Traditions are built up, whose sacrosanct character is soon taken for granted by all practitioners, and any skeptic who dares to question the usefulness of a tradition is likely to be looked upon with suspicion and distrust. This is not surprising since every modification of an established rule involves-beside the inevitable initial expense-readjustments of habits on the part of the library staff ; and it is a well-known psychological fact that the breaking of old habits and the adoption and incorporation of new patterns of action is usually upsetting and painful.

Professional meetings of librarians miss their main function, however, unless they deliberately encourage and cultivate a progressive and critical attitude among the participants-a critical attitude toward established library practices, a critical attitude toward the objectives which such practices are designed to fulfill, a critical attitude toward remnants of the past as well as toward innovations. It is in this spirit of open-mindedness and hospitality toward new ideas that the topic of college library book funds will be approached in this paper.

Let us begin with a very brief historical sketch. In their colonial days American college libraries did not have to cope with the problems in connection with the necessity of controlling book expenditures, for there was practically no money available for the purchase of new publications. Shores found that "the proportion of accessions acquired by direct purchase was probably less than a tenth of the total." 1 As was stated in the special report on American libraries, issued by the Bureau of Education in I 876, up to about the middle of the nineteenth century there were "few colleges [that] possessed funds to build up libraries on a scientific plan." Only very gradually, as the needs and objectives of college libraries became more sharply defined, were funds provided for the purchase of current books. Doubts began to be raised as to whether a haphazard conglomeration of private libraries was suitable for the use of college students.

There were several ways in which money could be secured. Endowments were established either by a single donor or through subscription. Special efforts were instituted to obtain gifts of money

\footnotetext{
1 Shores, Louis. Origins of the American College Library. Barnes \& Noble, 1935, p. I09. ${ }^{2}$ U.S. Bureau of Education. Public Libraries in Management. Special Report. Pt. I. Government Management. Special Report.
Printing Office, 1876 , p. 62 .
} 
from alumni and other friends of the college. Many of these funds were clearly earmarked for the purchase of books in designated fields. In such cases the library administrator was not confronted with the vexing task of having to distribute the money among the various academic disciplines. Only when the bulk of available money began to be obtained through student fees and regular annual appropriations did the problem of how to apportion the book fund appear on the scene and become pressing.

The natural tendency was to pool the money from the various sources into a single book fund of the library. Occasionally, however, this was not done, i.e., books were paid for out of funds belonging to the respective academic departments rather than out of a centralized library book fund. In such instances the librarian had obviously very little control over book selection. The library constituted merely the neutral depository of independent departmental acquisitions. The authority of the individual department of instruction was supreme. In the I 926 survey, conducted by the American Library Association, it was found that only six of a sample of fifty-four college and university libraries operated under this divided arrangement. ${ }^{3}$ The situation was less favorable among land-grant colleges and universities, where-as recently as 1930-it was found that in only five of forty-eight such institutions was there any supervision exercised by the librarian over the expenditure of funds for the purchase of departmental library books. ${ }^{4}$ Among 105 libraries of nationally accred-

${ }^{3}$ A Survey of Libraries in the United States. Vol. I. American Library Association, 1926, p. 217. ${ }^{4}$ U.S. Office of Education. Survey of Land-Grant Colleges. Section of Bulletin, 1930, No. 9, Vol. I, Pt. VIII, The Library. Government Printing Office, 1930, p. 652 . ited colleges (A.A.U. approval), surveyed by the author in I940, there was only a single case in which book funds were not centralized. ${ }^{5}$ It seems, therefore, that the trend is definitely in the direction of centralization.

Let us now turn to several controversial issues - as indicated by the following questions-concerning the handling of centralized book funds: (I) Should the book fund of a college library be apportioned among the several departments of instruction? (2) If so, how are the undesirable features of the apportionment plan to be removed or mitigated? (3) What records and memoranda are necessary and desirable in carrying out the apportionment plan?

\section{Apportionment versus Nonapportionment}

If we ask whether a library book fund should be apportioned or not, two kinds of answer are possible: (I) First, we may point to the practices of other libraries and recommend the adoption of whatever happens to be the most common practice. If this is done, we find that most college libraries undertake an official apportionment of their book funds every year. Among I05 college libraries, surveyed by the author, seventy-seven operated under formal apportionments. In almost all the thirty-five colleges related to the Methodist Episcopal Church, which were surveyed by Reeves and his staff, the book budget was apportioned among the several departments of instruction. ${ }^{6}$ Book funds were also apportioned in thirty-eight of fifty-four college and university li-

5 For a list of the colleges surveyed see Hans Muller's, "The Administration of Book Funds in Master's Report, Graduate Library School. Univer. sity of Chicago, I94I). istration of the "Library Book Budget." Library Quarterly $2: 269$, July ig32. 
braries surveyed in 1926 by the American Library Association. ${ }^{7}$ If the findings of these surveys are taken as evidence of what ought to be done, the conclusion must be drawn that to apportion the library book fund is better than not to apportion it.

(2) Another way of answering this question is to weigh advantages against disadvantages. The advantages may be briefly stated in the approximate order of their importance (as determined in part by a pooled judgment of college librari$\mathrm{ans}^{8}$ ): (a) apportionment ensures the obtaining of an evenly distributed and well-rounded book collection; (b) it provides a safeguard against unreasonable demands of certain faculty members; (c) it stimulates the faculty to participate more actively in book selection, since it enables departments to feel that there is some money available which they can call their own $;^{9}(\mathrm{~d})$ it guards the librarian against the possible charge that the expenditure of book funds has been unjust to some departments; (e) it prevents the clash of personalities ${ }^{10}$ (f) it curbs the exercise of an excessive degree of discretionary power and arbitrariness on the part of the librarians. ${ }^{11}$

\section{Disadvantages of Apportionment}

As to the disadvantages of the apportionment plan we note that Randall and Goodrich regard it as a necessary evil. ${ }^{12}$

7 A Survey of Libraries in the United States. Vol. I. American Library Association, I926, p. 220. 8 See Muller, op cit., for a detailed description ranks of these advantages.

ranks of these advantages. Falley in G. Moment's "Books and Money in Colleges." Special Library Association. Proceedings 2:1 24, I939.

Association. Proceedings "2:I 24, I939. Funds-A Defense." Library Journal 58:248, Mar. I 933 .

${ }^{11}$ Koch, Theodore W., et al. "The Apportionment of Book Funds in College and University Libraries." A.L.A. Bulletin 2:344, 1908 .

12 Principles of College Library Administration. American Library Association and University of Chicago Press, 1936, p. 59.
Whether it is really necessary is, of course, an open question in view of the fact that some college libraries do not officially operate under the apportionment plan. That "evils" are associated with the plan is usually not denied. They will be discussed under four heads: waste of funds; impossibility of planning; red tape; and rigidity.

Several writers have pointed out that apportionment leads to a waste of money. Some departments are bound to be allotted much less money than they need, whereas others have too much money to spend. ${ }^{13}$ Thus apportionment has the effect of hampering the departments that could really use the money. ${ }^{14}$

The apportionment plan is said to prevent any systematic building-up of the library book collection. ${ }^{15}$ Unless special provisions are made, no funds are available for the purchase of expensive sets, because the funds available to any given department usually revert to a general fund at the end of a fiscal year. Hence it is normally impossible to accumulate funds.

Complaints are occasionally voiced about the excessive amount of red tape and bookkeeping involved in the apportionment plan. This is particularly noticeable whenever changes during the course of the year seem desirable. Pitiful expedients have to be resorted to, such as petitions for transfers, ${ }^{16}$ and informal interdepartmental lending. ${ }^{17}$ In the attempt to use up the available funds, books are billed to be sent later. ${ }^{18}$ In general, it

13 Reeves and Russell, op. cit., p. $27 \mathrm{I}$.

14 Koch, et al., op. cit. p. ${ }^{142}$ Randall, W. M. The College Library. Ameri. can Library Association and University of Chicago Press, I932, p. I02.

The College and University Library. Preprint of Manual of Library Economy, chap. iv, 2d ed. American Library Association, I $9 \underset{17}{2}$ I, p. I 3.

18 Woch, et al., op. cit., p. 343 . 
must be granted that there is a great deal of apparently unnecessary bookkeeping, which tends to make the plan uneconomical. ${ }^{19}$

Librarians have also frequently complained about the tendency for apportionments to remain fixed for too long a period-in disregard of changes in the curriculum. The reason for this lack of flexibility is that changes are difficult to make, since no department is willing to consent to a reduction of its own allotment. ${ }^{20}$ Often no account is taken of variations in the relative publishing output of different subject fields from year to year.

Whether the advantages outweigh the disadvantages depends on a number of factors. No categorical answer can be given. Much depends on the professional competence of the librarian and the academic prestige which he commands. Much depends also on the traditions that prevail in a particular college. Most of the disadvantages can be controlled or prevented, provided that the librarian is alert to the ever-changing needs of the college community. Given an incompetent librarian, it is perhaps wise to insist on the retention of the apportionment plan.

\section{Remedies}

Several remedies have been proposed, which are designed to bring about an alleviation of the undesirable accompaniments of apportioning. Prominent among the suggestions as to how the evils of apportionment may be avoided is the plan put forth by Randall. ${ }^{21}$ He recommended a four-year cycle of apportionment, which

$$
19 \text { Ibid. }
$$

20 Van Patten, Nathan. "Buying Policies of College and University Libraries." College and Research Libraries 1:66. Dec. 1939.

21 Randall, op. cit., pp. $102-04$. would result in a periodic check-up of the book collection and which would make it possible to carry on a well-planned program of book purchases. Under this plan there would be a relatively large rotating fund, which would be assigned to a different department or group of departments every year. Thus a department would be given an opportunity to conduct recurrent surveys of the book collection in its particular field and to fill in gaps. This plan is reported to be in operation at the University of Denver.

A second plan is that described by McCrum. ${ }^{22}$ She would ask faculty members to indicate three degrees of preference on their book requisitions: (a) essential, (b) very desirable, but demand not pressing, (c) to round out the collection. The assumption is that the library has sufficient funds to purchase all the books in class $a$, and that the librarian may be permitted to use his discretion in selecting books from classes b and c, if enough money to purchase all the requested titles is not available. Cards for titles not immediately purchased are kept in a desiderata file. This plan is in operation at Macalester College, St. Paul.

A third plan is that followed at the University College, London, where funds are allotted by a faculty library committee, not to the individual departments of instruction, but to five subcommittees, each of which passes upon all the requisitions of a group of departments. ${ }^{23}$ The librarian is a member of each subcommittee and, thus, participates in the process of book selection. The idea underlying this

\footnotetext{
${ }^{22}$ McCrum, Blanche P. An Estimate of Standards for a College Library. $2 \mathrm{~d}$ ed. rev. Lexington, Tournalism Laboratory Press, Washington and Lee Tournalism Laboratory Press, Washington and Lee
University, 1937, pp. 105.06. University, 1937, pp. 105-06. B. S. A Manual of ${ }^{23}$ Woledge, G., and Page, B. S. A Manual of
University and College Library Practice. London, The Library Association, 1940, p. 42.
} 
plan is to prevent book selection from too narrow a point of view.

A fourth remedy is to provide a relatively large general fund, which would make it possible for the librarian to meet any emergencies. This plan has been highly recommended by many librarians. It represents perhaps-in a compromise fashion-the most desirable solution. The larger the general fund becomes, the more does the librarian pass from the order clerk stage to the book-selector stage. A general fund makes for elasticity in the book purchasing program and permits the acquisition of materials in borderline subjects. Randall and Goodrich maintain that an ample discretionary fund ought to be provided, so that the salary paid a competent librarian would not be wasted. ${ }^{24}$ How large the general fund will be, depends on the local situation. Among sixty-four liberal arts colleges surveyed by the author, the arithmetic mean was 28 per cent; the range extended all the way from zero to 70 per cent. Two distinctive modes were noted at 25 and 33.3 per cent respectively.

In another survey conducted by the author, a group of Middle Western college librarians was asked the following question: "What do you consider to be the maximum percentage of the total library book fund (exclusive of funds for periodicals and binding) that should be apportioned to departments annually?" The average answer (i.e., the arithmetic mean of all the answers) was 66 per cent. ${ }^{25}$ Thus the belief was expressed that about one third represents the minimum proportion of the total book fund that should be left under the exclusive jurisdiction of the librarian. This rec-

\footnotetext{
24 Randall and Goodrich, op. cit., p. 64.

${ }^{25}$ See Muller, $o p$. cit., p. 61 for the distribution of answers.
}

ommendation does not deviate from current practices. It should be noted, of course, that much depends upon the size of the total book fund. For instance, 40 per cent, as recommended by the librarian of one library, represented $\$ 3560$, whereas 50 per cent, as recommended by the librarian of another library, represented only $\$ 900$. These two situations are obviously not quite comparable.

A fifth method designed to remedy the undesirable features of the apportionment plan is the carrying-over of departmental allotments from one fiscal year to the next. If departmental book funds revert to a general college fund, the result is what Baker calls a "last-minute spending stampede." 26 The lapsing of funds can, of course, be prevented if the librarian sends reminders to the faculty throughout the year, informing them as to the status of their departmental allocations, so that by the end of the year most of the apportioned money will have been spent. However, if a considerable sum should remain unexpended, it is preferable to make some provision for the carrying-over of departmental apportionments. This can be accomplished in either one of two ways: (I) A library reserve fund may be created, which would absorb all the unspent balances; and through informal agreements the several departments would be permitted to let their book funds accumulate in this reserve fund even for a number of years. This was the practice at Cornell University and at the University of Missouri in $1908 .^{27}$

McCrum suggested a slightly different arrangement, under which funds could be deposited by the treasurer of the university in a separate fund to be spent for

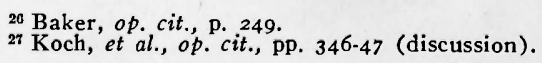


a definite item at a future time. ${ }^{28}$ In summary, it seems that under current methods of financial administration it is normally not possible to carry over departmental apportionments as departmental apportionments except through informal arrangements, under which such departmental apportionments as revert into a librarian's reserve fund may subsequently be spent by the departments to which the apportionment was originally made.

\section{Records and Memoranda}

Thus far we have discussed-after a brief historical introduction-the question of apportionment versus nonapportionment both in terms of relative advantages and disadvantages and in terms of frequency of occurrence. Assuming that a college library is to have an apportioned book fund, we have enumerated several ways of coping with the undesirable features that tend to accompany the apportionment plan. Special attention was paid to the problem of deciding upon the optimum size of the librarian's general fund. The remainder of the paper will be devoted to a consideration of records and memoranda.

Librarians have paid a good deal of attention to methods of accounting and record keeping. Speaking of the situation at the University of California, Leupp wrote that the library kept a record of the distribution of funds and that it could "show any bewildered professor in five minutes just where his account stands." It does not seem necessary in the present context to describe the various methods of bookkeeping in detail. Attention will be paid to the following two questions

${ }_{28}^{28} \mathrm{McCrum}$, op. cit., p. Io7.

${ }^{29}$ Leupp, Harold L. "The Library: the Heart of the University," Library Journal 49:620, July I924. only: (I) What policy should be followed with regard to the giving out of information about departmental allotments? (2) How often should departments be informed as to the balances remaining in their respective funds during the course of the year?

In a group of twenty libraries of nationally accredited liberal arts colleges, which were surveyed by the author with respect to book-fund administration, there were eleven libraries in which information about the allotment of a given department is made available only to a member of the department concerned. In seven libraries information is given to any faculty member who asks for it. The remaining two libraries go as far as to make the allotment figures known to faculty members by means of an official memorandum. It is interesting to note that such wide variations of policy exist. The fact that such a large number of libraries does not think it advisable to make apportionment figures public reflects perhaps the feeling that apportionments do not stand on very firm ground and that the administrators of those libraries find it difficult to defend them in the face of complaints.

In library literature free access to the apportionment records has often been looked upon with disfavor. Wyer, for instance, writes: $:^{30}$

The librarian (not the college finance office) will keep an account book which will show the sums spent each year for books, binding, and periodicals for each department. Naturally the sum for the same department will vary somewhat from year to year. These figures are never made public. The faculty committee may ask to see them but rarely will so long as there are no appeals.

The figures for a single department are

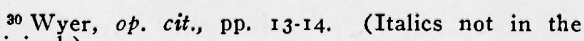
original.) 
sometimes made known to its head to show him how much he has had during the year, or that he has had more than some or any other departments, or quite as much as his share, but the complete figures are not public property.

Making it impossible for one department to know what another is spending for books may, of course, be a prudent way of avoiding unnecessary ill feeling. On the other hand, some librarians emphatically insist on publicizing the distribution of the book fund. Such an insistence reflects (a) the fact that the librarian's position is secure and powerful and that the librarian is not afraid of getting into an argument, and (b) it also reflects the commendable policy of a library to treat this whole subject in a democratic and open manner. To cite merely a single illustration, mention may be made of Williams College, where a mimeographed sheet, showing the allocation of funds to the several departments, is distributed among the faculty.

In the author's survey of book fund administration, previously referred to, it was asked how often department heads were informed as to the balances remaining in their respective allotted funds. The answers showed considerable variation. All the libraries send, of course, special statements on request at any time. One half of the libraries in this group sends statements at the rate of at least once every school term. The other half sends statements at irregular intervals or whenever a need for informing a department arises. Even though it is difficult to say what the best practice is, it does seem that relatively frequent statements would be an effective means of reminding the faculty of their book selection duties. Some authorities, on the other hand, main- tain that too frequent reminders have the effect of excessive stimulation and tend to lead to purchases of books that are not really needed in the instructional work of the college.

\section{Conclusion}

In conclusion it may be worth while to enumerate a few additional important problems which are relevant to the administration of book funds in college libraries but which-for lack of timecould not be touched upon in this paper. Nothing has been said about methods of determining the shares to be allocated to the several departments. What are the advantages of, and the objection to, the use of mathematical formulae? How much weight is to be attached to the various factors that presumably influence and determine the book needs of a department? A second group of problems would center around the effect of different types of book fund administration upon the quality of the resulting book collection.

A third problem would concern the relationship of the size of the book fund to the type of book fund administration that has been adopted in different colleges. A fourth problem would deal with the scope of apportionments, that is, the extent to which expenditures for materials other than books (for example, periodicals) would or should be covered by apportionments. A final problem would relate to matters of authority, supervision, and control, that is, to the respective roles of the president, the librarian, the dean, the business officer, and the faculty committee in deciding upon the distribution of the book fund and in authorizing transfers of funds during the course of the year. 